\title{
Implementasi Pembelajaran IPA Berbasis Inkuiri Terbimbing terhadap Kemampuan Literasi Sains Materi Pesawat Sederhana
}

\author{
Putri Ailana Yhawita Sari ${ }^{1 *}$, Nely Andriani ${ }^{2}$, Zulherman $^{3}$, Saparini $^{4}$ dan \\ Widya Rahmatika Rizaldi ${ }^{5}$ \\ $1^{\star}, 2,3,4,5$ Program Studi Pendidikan Fisika, FKIP Universitas Sriwijaya, Palembang, Sumatera Selatan \\ E-mail: putri ailana@yahoo.com
}

\begin{abstract}
Abstrak
Telah dilakukan penelitian bertujuan untuk mengetahui (1) adanya pengaruh pembelajaran IPA berbasis inkuiri terbimbing terhadap kemampuan literasi sains materi pesawat sederhana, dan (2) peningkatan kemampuan literasi sains siswa pada materi pesawat sederhana. Penelitian dilaksanakan di SMP Negeri 3 Gelumbang, Sumatera Selatan pada siswa kelas VIII 1. Metode penelitian yaitu kuasi eksperimen dengan one group pretest posttest design. Data dikumpulkan melalui tes dan selanjutnya dianalisis menggunakan uji t dan $\mathrm{N}$-gain. Hasil penelitian diperoleh $t_{\text {hitung }}=26,766>t_{\text {tabel }}=2,069$ sehingga $\mathrm{H}_{0}$ ditolak dan $\mathrm{H}_{\mathrm{a}}$ diterima, artinya pembelajaran IPA berbasis inkuiri terbimbing berpengaruh terhadap kemampuan literasi sains materi pesawat sederhana. Peningkatan kemampuan literasi sains siswa sebesar 0,4 termasuk kategori sedang.
\end{abstract}

Kata kunci: pesawat sederhana, literasi sains, inkuiri terbimbing.

\section{Abstract}

The research aimed to determine (1) the effect of guided inquiry-based science learning on scientific literacy skills in simple machines materials, and (2) increase students scientific literacy skills in simple machines material. The research was carried out at SMP Negeri 3 Gelumbang, South Sumatra in class VIII 1. The research method was quasi-experimental with one group pretest posttest design. Data were collected through tests then analyzed using the $t$ test and $N$-gain. The results showed that $t_{\text {count }}=26.766>t_{\text {table }}=2.069$ so that $H_{0}$ was rejected and $\mathrm{H}_{a}$ was accepted, meaning that guided inquiry-based science learning had an effect on scientific literacy skills in simple machines material. The increase in students scientific literacy skills by 0,4 was included in the moderate category.

Keywords: simple machine, scientific literacy, guided inquiry.

Article History: Received: 6 November 2020 Accepted : 6 November 2020
Revised : 10 November 2020

Published : 20 November 2020

How to cite:Sari, P. A.Y., Andriani, N., Zulherman, Saparini, \& Rizaldi, W.R. (2020). Implementasi Pembelajaran IPA Berbasis Inkuiri Terbimbing terhadap Kemampuan Literasi Sains Materi Pesawat Sederhana, 1(1). pp. 131 - 137. Retrieved from http://jurnal.fkip.unmul.ac.id/index.php/JLPF

Copyright (C November 2020, Jurnal Literasi Pendidikan Fisika 
Implementasi Pembelajaran IPA...

\section{PENDAHULUAN}

Pada hakikatnya pendidikan sains membahas tentang bagaimana membelajarkan peserta didik menuju pengembangan sikap positif. Pengembangan ini meliputi pemahaman sains sebagai produk dan proses serta aplikasinya, sikap ingin tahu, keteguhan hati, dan ketekunan, dan sadar akan nilai-nilai yang ada di masyarakat (Mariana \& Praginda, 2009). Namun demikian, penerapan pendidikan sains di Indonesia masih terbatas pada pelaksanaan penelitian di tingkat LPTK dan belum sepenuhnya dilaksanakan di sekolah. Hal tersebut ditunjukkan dari hasil penelitian yaitu pemahaman hakikat sains oleh guru dan siswa tergolong cukup (Adi \& Widodo, 2018).

Alternatif yang dapat dilakukan yaitu dengan menerapkan pembelajaran/pendidikan sains yang mengedepankan pada pengembangan sikap, gagasan, keterampilan proses sains yang menekankan pada kegiatan inkuiri ilmiah dengan seperti itu pembelajaran sains akan mampu meningkatkan kemampuan literasi sains siswa serta meningkatkan antusiasme, minat, dan kekaguman siswa akan sains (Yulianti, Y. 2017).

Secara sederhana, literasi adalah kemampuan membaca, memahami, mengelola, dan menggunakan informasi dalam berbagai konteks (Hartati, 2017), sedangkan literasi sains itu sendiri merupakan kemampuan seseorang menggunakan pengetahuannya dalam bidang sains, teknologi dan masyarakat dengan berpikir logis, informasi yang diperoleh menunjukkan seberapa jauh orang-orang menggunakan pengetahuan dan keterampilan untuk menghadapi tantangan kehidupan nyata, bukan hanya pada penguasaan dalam kurikulum sekolah dapat dilihat dari hasil assesmen PISA (OECD, 2012).

Penerapan literasi sains dalam pembelajaran IPA di sekolah harus melalui kegiatan-kegiatan ilmiah yang mecakup tiga komponen penting, yaitu IPA sebagai proses, IPA sebagai produk dan pengembangan sikap. Oleh karena itu, kegiatan pembelajaran di sekolah harus mendukung kemampuan literasi siswa seperti praktikum, pembuatan karya ilmiah, problem solving, diskusi ilmiah, dll.
Literasi sains merupakan salah satu ranah studi PISA. Pada PISA 2006 dimensi literasi sains dikembangkan menjaidi empat aspek dimensi diantaranya dimensi pengetahuan yang merupakan pemahaman tentang fakta-fakta utama, dan teori-teori penjelasan yang membentuk dasar pengetahuan ilmiah. Pengetahuan tersebut meliputi pengetahuan tentang alam dan teknologi artefak, pengetahuan tentang bagaimana ide-ide tersebut diproduksi dan pemahaman Itentang alasan yang mendasari untuk prosedur ini dan pembenaran yang mereka gunakan. Aspek pengetahuan terdiri atas beberaa konten yaitu konten fisik, kehidupan, serta bumi dan antariksa. Salah satunya terdiri atas konten sistem fisik yang terdiri atas materi gerak dan kekuatan dan tindakan dari jauh, sifat materi, interaksi antara energi dan materi, struktur materi, energi dan transformasinya, dan perubahan kimia materi (OECD, 2013).

Materi yang digunakan pada penelitian ini adalah materi pesawat sederhana dan berhubungan juga dengan konsep gaya. Pesawat sederhana tidak bekerja dengan sendirinya, namun pesawat sederhana membutuhkan gaya kuasa. Karena pesawat sederhana dapat mengubah arah gaya kuasa. Pesawat sederhana menggunakan satu gaya kerja untuk bekerja melawan satu gaya beban dengan mengabaikan gaya gesek. Pesawat sederhana ini gunanya untuk memudahkan pekerjaan manusia. Materi ini erat kaitannya dengan peristiwa dalam kehidupan sehari-hari siswa yang bisa mengukur kemampuan literasi siswa.

Kurikulum yang digunakan saat ini adalah kurikulum 2013 dimana dijelaskan bahwa ada tiga hal yang harus dicapai oleh peserta didik yaitu karakter, kompetensi, dan literasi. Model pembelajaran yang dipandang sesuai untuk meningkatkan kemampuan literasi peserta didik adalah model pembelajaran inkuiri terbimbing, karena model ini memiliki langkah-langkah pembelajaran yang dapat membuat peserta didik menjadi aktif dan menemukan sendiri konsep-konsep yang dipelajari. Hasil penelitian yang telah digunakan oleh Nuur Lelawati (2015) menunjukkan bahwa terdapat perbedaan peningkatan kemampuan literasi sains peserta 
Implementasi Pembelajaran IPA...

didik yang signifikan antara kelas yang menerapkan model pembelajaran inkuiri dan kelas yang tidak menerapkan model pembelajaran inkuiri terbimbing. Hasil peningkatan literasi sains peserta didik dari $49,50 \%$ menjadi $64,50 \%$ hal itu karena adanya pelatihan menggunakan model pembelajaran inkuiri. Penelitian serupa yang dilakukan oleh Ngertini, Sadia, \& Yudana (2013) menunjukkan bahwa model pembelajaran inkuiri terbimbing memberikan pemahaman konsep lebih optimal dibandingkan dengan model pembelajaran langsung. Hal ini dikarenakan pembelajaran inkuiri terbimbing merupakan model pembelajaran yang berlandaskan pandangan konstruktivisme bahwa pembelajaran dengan mengkonstruksi sendiri pengetahuannya, sehingga sangat sesuai sebagai alternatif pembelajaran sains khususnya dalam pencapaian pemahaman konsep dan literasi sains.

Dari latar belakang uraian diatas, peneliti bermaksud untuk melakukan penelitian dengan judul "Implementasi Pembelajaran IPA Berbasis Inkuiri Terbimbing terhadap Kemampuan Literasi Sains Materi Pesawat Sederhana".

\section{METODE}

Penelitian ini menggunakan metode kuasi eksperimen atau eksperimen semu. Desain penelitian yang digunakan adalah one group pre-test post-test design. Dalam penelitian ini hanya menggunakan satu kelompok siswa tanpa adanya kelompok pembanding.

Tabel 1. One Group Pre-test Post- test Design

\begin{tabular}{ccc}
\hline Pre-Test & Perlakuan & Post-Test \\
\hline O1 & $\mathrm{X}$ & $\mathrm{O} 2$ \\
\hline & & (Sugiyono,2015)
\end{tabular}

Pengumpulan data dilakukan dengan cara teknik tes dan non tes. Teknik tes dilakukan dengan cara memberikan soal essay kepada peserta didik. Sedangkan teknik non tes adalah lembar observasi keterlaksaan pembelajaran. Pengumpulan data dilakukan di SMP Negeri 3 Gelumbang dengan sampel 24 peserta didik kelas VIII yang dipilih dengan teknik purposive sampling. Cara menganalisis data yang telah dikumpulkan yaitu dengan $U j i t$, dan $N$-gain .

\section{HASIL DAN PEMBAHASAN HASIL}

Analisis data tes dimulai dengan uji normalitas dan homogenitas setelah memberi pretest dan posttest. Hasil uji normalitas data pretest dan posttest menggunakan uji Shapiro Wilk dengan bantuan program SPSS 22 for Windows dapat dilihat pada tabel 2 sebagai berikut:

Tabel 2. Hasil Uji Normalitas Data

\begin{tabular}{cccc}
\hline \multicolumn{4}{c}{ Shapiro-Wilk } \\
\hline Data & Statistics & Df & Sig \\
Pretest & 0,979 & 24 & 0,877 \\
Posttest & 0,940 & 24 & 0,164 \\
\hline
\end{tabular}

Setelah dilakukan uji normalitas, dilakukan uji homogenitas dengan hasil yang ditampilkan oleh tabel 3 sebagai berikut:

Tabel 3. Hasil Uji Homogenitas

\begin{tabular}{|c|c|c|c|c|c|c|}
\hline \multicolumn{3}{|c|}{$\begin{array}{c}\text { Levene } \\
\text { Statistics }\end{array}$} & df1 & df 2 & & Sig. \\
\hline \multicolumn{3}{|c|}{0,05} & 1 & 46 & & 0,944 \\
\hline \multicolumn{7}{|c|}{$\begin{array}{l}\text { Hasil uji hipotesis ditampilkan pada tabel } 4 \\
\text { sebagai berikut: }\end{array}$} \\
\hline \multicolumn{7}{|c|}{ Tabel 4. Tabel Uji Hipotesis } \\
\hline \multirow{3}{*}{\multicolumn{2}{|c|}{$\mathrm{T}$}} & & & & & \\
\hline & & \multirow[t]{2}{*}{ df } & \multirow{2}{*}{$\begin{array}{l}\text { Sig. } \\
(2- \\
\text { failed })\end{array}$} & \multirow[t]{2}{*}{$\begin{array}{l}\text { Mean } \\
\text { Differe } \\
\text { nce }\end{array}$} & \multicolumn{2}{|c|}{$\begin{array}{l}95 \% \text { confidence } \\
\text { interval of the } \\
\text { Difference }\end{array}$} \\
\hline & & & & & Lower & Upper \\
\hline $\begin{array}{l}\text { Post } \\
\text {-test }\end{array}$ & 26,7 & 23 & .000 & 63,195 & 58,310 & 68,079 \\
\hline
\end{tabular}

Hasil uji normalitas data yang bertujuan untuk mengidentifikasi peningkatan hasil belajar siswa setelah diterapkannya model pembelajaran inkuiri terbimbing dinyatakan dalam skor gain normalisasi nilai rata-rata siswa dapat dilihat pada tabel 5 sebagai berikut:

Tabel 5. Hasil Uji Gain Ternormalisasi

\begin{tabular}{cccccc}
\hline & $\begin{array}{c}\text { Pre- } \\
\text { test }\end{array}$ & $\begin{array}{c}\text { Post- } \\
\text { test }\end{array}$ & G & $<$ g & Kategori \\
\hline $\begin{array}{l}\text { Rata } \\
\text {-rata }\end{array}$ & 38,47 & 63,19 & 24,723 & 0,40 & Sedang \\
\hline
\end{tabular}

Hasil rata-rata presentase keterlaksanaan pembelajaran per indikator pada tiap pertemuan dan seluruh pertemuan dapat dilihat pada tabel 6 sebagai berikut: 
Implementasi Pembelajaran IPA...

Tabel 6. Rata-rata Persentase Keterlaksanaan Pembelajaran per Indikator pada Tiap Pertemuan dan Seluruh Pertemuan

\begin{tabular}{|c|c|c|c|c|c|}
\hline \multirow{2}{*}{ Indikator } & \multicolumn{3}{|c|}{ Pertemuan Ke- } & \multirow{2}{*}{$\begin{array}{l}\text { Rata- } \\
\text { rata } \\
(\%) \\
\end{array}$} & \multirow{2}{*}{$\begin{array}{l}\text { Kategori } \\
\text { aktivitas }\end{array}$} \\
\hline & 1 & 2 & 3 & & \\
\hline Orientasi & 100 & 100 & 100 & 100 & $\begin{array}{c}\text { Sangat } \\
\text { Baik }\end{array}$ \\
\hline $\begin{array}{l}\text { Merumuskan } \\
\text { masalah }\end{array}$ & 66,66 & 54,16 & 58,33 & 59,72 & Sedang \\
\hline $\begin{array}{l}\text { Merumuskan } \\
\text { hipotesis }\end{array}$ & 70,83 & 62,50 & 66,66 & 66,66 & Baik \\
\hline $\begin{array}{c}\text { Mengumpulkan } \\
\text { dan Menganalisis } \\
\text { Data }\end{array}$ & 85,41 & 87,5 & 89,58 & 87,5 & $\begin{array}{l}\text { Sangat } \\
\text { Baik }\end{array}$ \\
\hline $\begin{array}{c}\text { Inferensi } \\
\text { Generalisasi }\end{array}$ & $\begin{array}{c}70,83 \\
75\end{array}$ & $\begin{array}{l}79,16 \\
58,33\end{array}$ & $\begin{array}{l}66,66 \\
66,66\end{array}$ & $\begin{array}{l}72,22 \\
66,66\end{array}$ & $\begin{array}{l}\text { Baik } \\
\text { Baik }\end{array}$ \\
\hline Refleksi & 100 & 100 & 100 & 100 & $\begin{array}{c}\text { Sangat } \\
\text { Baik }\end{array}$ \\
\hline \multicolumn{4}{|c|}{ Jumlah keseluruhan indikator } & 78,96 & Baik \\
\hline
\end{tabular}

\section{PEMBAHASAN}

Penelitian mengenai Proses Pembelajaran IPA dengan menggunakan model inkuiri terbimbing di SMP Negeri 3 Gelumbang bertujuan untuk melihat peningkatan literasi sains di kelas VIII. Setelah diterapkan model pembelajaran inkuiri terbimbing dengan keterlaksanaan yang ditinjau dari ketuntasan belajar peserta didik yang terlihat dari rata-rata gain ternormalisasi dari nilai pretest dan posttest siswa. Diperoleh rata-rata untuk nilai pretest sebesar 38,47 , untuk rata-rata posttest didapatkan rata-rata sebesar 63,19 yang dapat dilihat pada tabel 1. Dilihat dari data tersebut menunjukkan adanya peningkatan yang signifikan setelah diberikan perlakuan pembelajaran dengan menggunakan model inkuiri terbimbing dengan pokok bahasan pesawat sederhana.

Setelah diperoleh data hasil pretest dan posttest siswa maka langkah selanjutnya adalah menganalisis dengan statistik. Karena dalam analisis ini menggunakan uji one sample $t$ test yang termasuk dalam statistik parametrik maka sebelum dilakukan uji hipotesis dengan menggunakan one sample $t$ test dilakukan uji normalitas dan uji homogenitas dengan menggunakan bantuan program SPSS 22 for Windows.

Uji normalitas dilakukan dengan menggunakan uji Shapiro Wilk karena sampel dalam penelitian ini berjumlah 24 orang.
Berdasarkan hasil data uji normalitas yang telah dilakukan didapatkan nilai signifikansi 0,877 untuk data pretest dan 0,164 untuk data posttest lebih besar dari 0,05 maka dapat disimpulkan bahwa data tersebut berdistribusi normal.

Setelah dilakukan uji normalitas dan data tersebut dinyatakan normal maka langkah selanjutnya adalah uji homogenitas. Uji homogenitas ini dilakukan dengan menggunakan Levene pada program SPSS 22 for Windows. Dari hasil uji normalitas didapatkan nilai signifikan sebesar 0,944 . Jika nilai signifikansi yang didapat lebih besar dari 0,05 maka data tersebut dinyatakan homogen. Setelah melakukan uji normalitas dan uji homogenitas dan terbukti bahwa data yang dihasilkan berdistribusi normal dan homogen dapat melanjutkan pada tahap uji hipotesis.

Uji hipotesis pada penelitian ini menggunakan uji one sample $t$ test dengan bantuan program SPSS 22 for Window dengan kriteria pengambilan keputusan hasil signifikansi dan thitung. Pada tabel 3 uji one sample $t$ test didapatkan hasil signifikansi (2tailed) sebesar 0,000 dan thitung sebesar 26,766. Uji ini termasuk kedalam uji dua pihak, maka kriteria signifikansinya dibagi menjadi dua yakni menjadi 0,025 . Karena nilai signifikansi yang didapat pada tabel sebesar 0,000 artinya lebih kecil dari 0,025 maka $\mathrm{H}_{\circ}$ ditolak dan $\mathrm{H}_{\mathrm{a}}$ diterima. Kemudian pengambilan keputusan berdasarkan thitung 
Implementasi Pembelajaran IPA...

yang dibandingkan dengan ttabel. Untuk menentukan harga ttabel terlebih dahulu menentukan nilai signifikansi $(\alpha=0,05)$ maka didapat nilai ttabel sebesar 2,069. Karena thitung > ttabel $(26,766>2,069)$ maka $\mathrm{H}_{\circ}$ ditolak dan $\mathrm{H}_{\mathrm{a}}$ diterima, sehingga dapat disimpulkan bahwa ada peningkatan hasil belajar siswa dengan menggunakan model pembelajaran inkuiri terbimbing di SMP Negeri 3 Gelumbang berupa penguasaan literasi sains pada aspek kompetensi yang meliputi menjelaskan fenomena ilmiah, mengevaluasi dan merancang penyelidikan ilmiah, dan menafsirkan dan bukti secara ilmiah.

Setelah dilakukan uji hipotesis, selanjutnya untuk mengetahui besar peningkatan literasi sains siswa di SMP Negeri 3 Gelumbang menggunakan model pembelajaran inkuiri terbimbing dilakukan analisis $\mathrm{N}$-Gain menggunakan nilai pretest dan posttest. Nilai posttest dan pretest digunakan untuk mengetahui gain dan rata-rata gain ternormalisasi dimana gain ternormalisasi ini bertujuan untuk mengetahui peningkatan hasil belajar setelah diterapkannya model pembelajaran inkuiri terbimbing. Berdasarkan hasil uji gain ternormalisasi didapatkan ratarata pretest sebesar 38,47 dan nilai posttest sebesar 63,195 sehingga diperoleh peningkatan literasi sains peserta didik (gain) sebesar 24,72 dan gain ternormalisasi sebesar 0,40 yang menunjukkan adanya peningkatan hasil belajar siswa menggunakan model pembelajaran inkuiri terbimbing berkategori sedang.

Peneliti melakukan penilaian keterlaksanaan pembelajaran yang muncul selama proses pembelajaran dengan menggunakan model pembelajaran inkuiri terbimbing melalui lembar observasi yang dibantu oleh observer. Data observasi diperoleh dengan melakukan pengamatan terhadap aktivitas belajar siswa selama proses pembelajaran dengan model pembelajaran inkuiri terbimbing. Lembar observasi yang digunakan sesuai dengan tahap-tahap pembelajaran inkuiri terbimbing. Data yang diambil dengan menggunakan lembar observasi dianalisa dan dihitung ratarata persentase aktivitas belajar siswa per indikator untuk tiga pertemuan dan keseluruhan pertemuan, kemudian menghitung rata-rata persentase aktivitas belajar siswa per indikator selama proses pembelajaran dengan menggunakan model pembelajaran inkuiri terbimbing. Hasil ratarata persentase keterlaksaan pembelajaran bervariasi per indikatornya yaitu indikator orientasi sebesar $100 \%$ berkategori sangat baik, dimana pada tahap ini guru memberikan apresiasi dan motivasi serta memperkenalkan dan mengarahkan topik. Kemudian pada indikator merumuskan masalah poinn penelitian terhadap peserta didik yaitu ketika berdiskusi untuk merumuskan masalah dan didapat hasil persentase sebesar $59,72 \%$ berkategori sedang, pada indikator merumuskan hipotesis poin penilaian terhadap peserta didik adalah berdiskusi untuk merumuskan masalah dan hipotesis didapat hasil persentase sebesar $66,66 \%$ berkategori baik. Kemudian indikator mengumpulkan dan menganalisis data poin penilaian pada indikator ini yaitu peserta didik melaksanakan kegiatan percobaan atau pengambilan data dan mendiskusikan data yang diperoleh dengan kelompok didapat persentase sebesar $87,5 \%$ berkategori sangat baik dan ada beberapa hal yang tidak ikut berpartisipasi untuk melakukan percobaan. Kemudian indikator inferensi sebesar 72,22\% berkategori baik dilakukan dengan cara guru meminta seorang peserta didik yang kurang aktif pada indiator sebelumnya untuk maju kedepan kelas bersama kelompoknya yang aktif dan ternyata menunjukkan bahwa peserta didik yang kurang aktif tadi menjadi lebih aktif. Selanjutnya indikator generalisasi persentase yang didapatkan sebesar $66,66 \%$ berkategori baik karena hanya beberapa peserta didik yang mampu merumuskan kesimpulan dengan baik. Terakhir yaitu indikator refleksi sebesar $100 \%$ berkategori sangat baik dimana hal ini menunjukkan peserta didik selama mengikuti pembelajaran dengan model inkuiri terbimbing mereka aktif dan mampu mengikuti serta melaksanakan pembelajaran sesuai dengan tahapan inkuiri 
Implementasi Pembelajaran IPA...

terbimbing. Keseluruhan indikator keterlaksanaan model pembelajaran inkuiri terbimbing hasil rata-rata persentasenya sebesar 78,96\% dengan kategori baik.

Berdasarkan pemaparan di atas, tampak bahwa keterlaksanaan proses pembelajaran selama menggunanakan model pembelajaran inkuiri terbimbing adalah baik. Model pembelajaran inkuiri juga mampu meningkatkan literasi sains peserta didik pada konten fisik di SMP Negeri 3 Gelumbang Didukung dengan peningkatan literasi sains dalam kategori sedang. Hasil penelitian ini selaras dengan penelitian yang dilakukan Didit (2016) dengan hasil yang didapat bahwa pembelajaran IPA dengan model inkuiri terbimbing dapat meningkatkan kemampuan literasi sains baik aspek konten, proses dan sikap sains. Capaian konten, proses dan sikap sains siwa secara keseluruhan mengalami peningkatan dalam kategori sedang. Hal ini dikarenakan peserta didik mampu mengikuti pembelajaran dengan baik namun salah satu kesulitan yang dialami peserta didik yaitu dalam merumuskan masalah hal ini disebabkan karena peserta didik kurang aktif dalam berkelompok. Kesulitan yang dialami guru ketika proses pembelajaran berlangsung yaitu guru sulit mengkondisikan peserta didik untuk fokus selama pembelajaran berlangsung. Hal ini selaras dengan penelitian yang dilakukan oleh Azizah (2016) bahwa faktor penghambat proses pembelajaran IPA dengan menggunakan model inkuiri terbimbing yaitu pengelolaan kelas yang kurang optimal dari guru. Sehingga guru mengalami kesulitan untuk memberikan penjelasan materi. Hasil penelitian ini, diketahui bahwa pembelajaran inkuiri terbimbing dapat membantu meningkatkan literasi sains peserta didik.

Berdasarkan hasil tersebut disimpulkan bahwa pembelajaran inkuiri terbimbing dapat membantu meningkatkan literasi sains peserta didik. Hasil penelitian ini selaras dengan penelitian yang dilakukan oleh Wahyudi (2013) dengan hasil terdapat peningkatan pada keterampilan proses sains dan adanya peningkatan hasil belajar setelah diterapkannya pembelajaran inkuiri terbimbing dimana untuk seluruh aspek yang masuk dalam ranah keterampilan proses sains tergolong baik.

\section{PENUTUP}

Berdasarkan tujuan dari hasil penelitian dan pembahasan yang telah dilakukan, dapat disimpulkan bahwa terdapat peningkatan literasi sains dengan menggunakan model pembelajaran inkuiri terbimbing di SMP Negeri 3 Gelumbang dengan rata-rata nilai pretest sebesar $38,47 \%$ dan rata-rata nilai posttest sebesar $63,19 \%$. Hal ini ditunjukkan dengan hasil $\mathrm{N}$-gain sebesar 0,4 dengan kategori sedang, yang berarti pembelajaran inkuiri mampu meningkatkan literasi sains peserta didik pada konten fisik di SMP Negeri 3 Gelumbang. Kemudian secara statistik menggunakan uji one sample $t$ test nilai hitung yang didapat sebesar 26,766 dengan $t$ tabel sebesar 2,069 serta taraf signifikan $\alpha=0,05$. Dikarenakan $\mathrm{t}$ hitung $>\mathrm{t}$ tabel, maka disimpulkan terdapat peningkatan setelah diterapkannya pembelajaran meggunakan model inkuiri terbimbing. Kemudian pencapaian keterlaksanaan pembelajaran inkuisi terbimbing sebesar $78,96 \%$ dengan kategori baik.

\section{DAFTAR PUSTAKA}

Azizah, Jayadiata, \& Gusrayani. (2016). Pengaruh Model Pembelajaran Inkuiri Terbimbing Terhadap Keterampilan Berpikir Kritis Peserta Didik pada Materi Energi Bunyi. Jurnal Pena Ilmiah, 1(1), 0-10.

Ardianto, Didit \& Rubini, B. (2016). Literasi Sains dan Aktivitas Siswa pada Pembelajaran IPA Terpadu Tipe Shared. Unnes Science Educational Journal. 5(1). 1153-1159.

Hartati, T. (2017). Multimedia dalam Pengembangan Literasi di Sekolah Dasar Terpencil Jawa Barat. Edutech, 15 (3), 301310.

Lelawati, N. (2015). Penerapan Model Pembelajaran Inkuiri untuk Meningkatkan Literasi Sains Peserta Didik pada Konsep Sistem Pertahanan Tubuh Kelas XI di MAN Babakan Ciwaringin. Skripsi, tidak dipublikasikan. Institut Agama Islam Negeri (IAIN) Syekh Nurjati Cirebon.

Ngertini, Sadia, \& Yudana. (2013). Pengaruh 
Implementasi Model Pembelajaran Inkuiri Terbimbing terhadap Kemampuan Pemahaman Konsep dan Literasi Sains Siswa Kelas X SMA PGRI 1 Amlapura. EJournal Program Pascasarjana Universitas Pendidikan Ganesh, 4(1), 1-11.

O.E.C.D. 2012. PISA 2012 Result: What Student Know and Can DO, 1. OECD. 2013. PISA 2015 Draft Science Framework. OECD.

Priyatno, D. 2009. Mandiri Belajar SPSS. Jakarta: Mediakom.

. 2010. SPSS untuk Analisa Korelasi, Regresi, dan Multivariate. Yogyakarta: Gava Media.

Wahyudi. 2013. Penerapan Model Pembelajaran Inkuiri Terbimbing pada Pokok Bahasan Kalor untuk Melatihkan Keterampilan Proses Sains terhadap Hasil Belajar di SMAN 1 Sumenep. Jurnal Inovasi Pendidikan Fisika, 2(2). 62-65.

Yuliati, Y. 2017. Literasi Sains dalam Pembelajaran IPA. Jurnal Cakrawala Pendas, 3(2), 21-28 